\title{
The content of apoptosis mediators in children with anemia of inflammation acquired on the background of acute bacterial diseases of respiratory organs
}

\author{
H. O. Lezhenko ${ }^{\star A, E, F}$, A. V. Abramov ${ }^{\mathrm{E}}$, A. O. Pohribna ${ }^{\mathrm{B}-\mathrm{D}}$ \\ Zaporizhzhia State Medical University, Ukraine
}

A - research concept and design; B - collection and/or assembly of data; C - data analysis and interpretation; D - writing the article;

$\mathrm{E}$ - critical revision of the article; $\mathrm{F}$ - final approval of the article

Aim. Determine the activity of apoptosis processes in young children with anemia of inflammation acquired on the background of acute bacterial diseases of respiratory organs.

Material and methods. The content of caspase- 7 and caspase- 9 was identified in blood serum of 87 kids by the method of immunoenzyme assay. Main group included 57 kids with acute bacterial diseases of the respiratory tract (38 patients had acute bacterial bronchitis, 19 - pneumonia).

The main group was divided into two subgroups. The first subgroup included 27 children with developed anemia of inflammation acquired on the background of acute bacterial disease of the respiratory tract. Second subgroup - 30 children with acute bacterial diseases of the respiratory tract without anemia. Experimental group - 10 children with iron deficiency anemia without symptoms of inflammatory diseases of the respiratory system. The control group was represented by 20 conditionally healthy children.

Results. The presence of pneumonia in children was accompanied by the highest numbers of caspase- $9(14.8 \pm 1.8 \mathrm{ng} / \mathrm{ml})$, which was almost 3 times higher than the control group $(5.82 \pm 0.58 \mathrm{ng} / \mathrm{ml})$. The levels of the studied enzyme were 1.6 times lower in patients with bacterial bronchitis $(8.34 \pm 0.90 \mathrm{ng} / \mathrm{ml})$, which was significantly higher $(P<0.05)$ than in the control group.

The content of caspase- 7 in the experimental group and the $2^{\text {nd }}$ subgroup of the main group did not differ from the control group $(P>0.05)(0.38 \pm 0.03 \mathrm{ng} / \mathrm{ml}$ and $0.32 \pm 0.02 \mathrm{ng} / \mathrm{ml})$, and children of the $1^{\text {st }}$ subgroup $(0.27 \pm 0.02 \mathrm{ng} / \mathrm{ml})$ showed its significant decrease.

Conclusions. Anemia of inflammation in children with acute bacterial diseases of respiratory organs is accompanied by the activation of apoptosis, which, obviously, is inefficient due to the nature of the active necrotic processes acquired on the background of acute inflammation.

\section{Вміст медіаторів апоптозу в дітей з анемією запалення, що виникиа на тлі гострих бактеріальних захворювань органів дихання}

\section{Г. О. Аеженко, А. В. Абрамов, А. О. Погрібна}

Мета роботи - визначення активності процесів апоптозу в дітей раннього віку з анемією запалення на тлі гострих бактеріальних захворювань органів дихання.

Матеріали та методи. Визначили вміст каспази-7, каспази-9 у сироватці крові 87 дітей віком від 2 місяців до 3 років (середній вік пацієнтів - 1,6 0 0,3 року) методом імуноферментного аналізу. Основну групу становили 57 дітей із гострими бактеріальними захворюваннями респіраторного тракту, серед них у 38 пацієнтів діагностували гострий бактеріальний бронхіт, а в 19 дітей - пневмонію.

Пацієнтів основної групи поділили на дві підгрупи: перша - 27 дітей, в яких на тлі гострого бактеріального захворювання респіраторного тракту розвинулась анемія запалення; друга - 30 дітей із гострими бактеріальними захворюваннями респіраторного тракту без проявів анемії. Група порівняння - 10 дітей із залізодесріцитною анемією без проявів запальних захворювань органів дихання. Контрольна група представлена 20 умовно здоровими дітьми. Групи спостереження репрезентативні за віком і статтю дітей.

Результати. Встановили, що наявність пневмонії в дітей супроводжувалася найвищими показниками вмісту каспази-9 (14,8 $\pm 1,8$ нг/мл), що майже втричі перевищував показники контрольної групи (5,82 $\pm 0,58$ нг/мл). Водночас рівні досліджуваного ферменту у хворих із бактеріальним бронхітом були в 1,6 раза нижчими (8,34 $\pm 0,9$ нг/мл), що вірогідно більше $(p<0,05)$, ніж у контрольній групі.

Вміст каспази-7 у сироватці крові дітей із групи порівняння та з другої підгрупи основної групи не відрізнявся від показників контрольної групи (0,38 $\pm 0,03$ нг/мл і 0,32 $\pm 0,02$ нг/мл відповідно, $p>0,05)$, а в дітей першої підгрупи виявили його вірогідне зниження $(0,27 \pm 0,02$ нг/мл).

Висновки. Анемія запалення в дітей, які хворі на гострі бактеріальні захворювання органів дихання, супроводжувалася активацією апоптозу, який, очевидно, мав неефективний характер через активні некротичні процеси, що відбувалися на тлі гострого запалення.
Key words: infants, respiratory tract diseases, caspase-7, caspase-9, anemia of inflammation.

Pathologia 2019; 16 (2), 177-181 DOI: 10.14739/2310-1237. 2019.2.177112

*E-mail: genalezh@gmail.com
Киючові слова: Аіти, захворювання Аихальних шляхів, каспаза-7, каспаза-9, анемія запалення.

Патологія. - 2019. T. 16, № 2(46). C. 177-181 
Ключевые слова: младенцы, болезни Аыхательных путей, каспаза-7, каспаза-9, анемия воспаления.

Патология. - 2019. -

T. 16, № 2(46). -

C. 177-181

\section{Содержание медиаторов апоптоза у детей с анемией воспаления, возникшей на фоне острых бактериальных заболеваний органов дыхания}

\section{Г. А. Аеженко, А. В. Абрамов, А. А. Погребная}

Цель работы - определение активности процессов апоптоза у детей раннего возраста с анемией воспаления на фоне острых бактериальных заболеваний органов дыхания.

Материалы и методы. Определили содержание каспазы-7, каспазы-9 в сыворотке крови 87 детей в возрасте от 2 месяцев до 3 лет (средний возраст пациентов - 1,6 \pm 0,3 года) методом иммуноферментного анализа. Основную группу составили 57 детей с острыми бактериальными заболеваниями респираторного тракта, среди которых у 38 пациентов диагностирован острый бактериальный бронхит, а у 19 детей - пневмония.

Пациенты основной группы разделены на две подгруппы: первая - 27 детей, у которых на фоне острого бактериального заболевания респираторного тракта развилась анемия воспаления; вторая - 30 детей с острыми бактериальными заболеваниями респираторного тракта без проявлений анемии. Группу сравнения составили 10 детей с железодефицитной анемией без проявлений воспалительных заболеваний органов дыхания. Контрольная группа представлена 20 условно здоровыми детьми. Группы наблюдения репрезентативны по возрасту и полу детей.

Результаты. Установлено, что наличие пневмонии у детей сопровождалось наиболее высокими цифрами каспазы-9 $(14,8 \pm 1,8$ нг/мл), что практически в 3 раза превышало показатели контрольной группы (5,82 \pm 0,58 нг/мл). Уровень изучаемого фермента у больных с бактериальным бронхитом был в 1,6 раза ниже (8,34 $\pm 0,9$ нг/мл), что достоверно больше $(p<0,05)$, чем в контрольной группе.

Содержание каспазы-7 в сыворотке крови детей группы сравнения и 2 подгруппы основной группы не отличалось от показателей контрольной группы (0,38 $\pm 0,03$ нг/мл и 0,32 $\pm 0,02$ нг/мл соответственно, $p>0,05)$, а у детей 1 подгруппы отмечено его достоверное снижение (0,27 $\pm 0,02$ нг/мл).

Выводы. Анемия воспаления у детей, больных острыми бактериальными заболеваниями органов дыхания, сопровождается активацией апоптоза, который, очевидно, носит неэффективный характер за счет активных некротических процессов, происходящих на фоне острого воспаления.

Apoptosis is a complex form of programmed cell death. First of all, it has a fundamental role in morphogenetic processes and in regulated control over the correct number of cells over the entire ontogeny of the organism. Apoptosis includes three phases that are independent of each other: the initiation phase, the effector phase, and degradation [1]. Apoptosis processes are transformed by activation of cysteine caspases - members of the central link of the proteolytic system, which are both initiators and implementers of cell death. Caspase-2, caspase-8, caspase -9 are among the activators of apoptosis. Caspase-3, caspase-6, caspase-7 are among caspases with effector function. In turn, the function of caspase-1, caspase- 4 , caspase- 5 is to provide processing and activation of cytokines, in particular, interleukins IL-1 $1 \beta, I L-18$. Carrying out the cell death through caspase activity means the breakdown of intracellular proteins, which leads to DNA fragmentation and cell destruction. However, caspase-9 initiates the mitochondrial process of cell death [2].

At the present stage caspases are studied in terms of oncological processes, the leading factor of which is the inhibition of apoptosis [3]. The same reason is leading in the pathogenesis of atopic and autoimmune diseases [4]. In turn, increased apoptosis in excess of the norm is observed in neurodegenerative, dysplastic processes and ischemic organ damages [5]. Violation of the implementation of apoptosis is the basis for the chronic infectious diseases formation. Despite the fact that the mechanism of necrosis has a leading role in inflammatory process, during the elimination of activated immune system cells, which performed their functions, - apoptosis comes into play in the final stages. In this regard, the variability of its values may reflect the course of the immunopathological process [6].
Studies in the field of cell death in pediatrics are not numerous. In particular, questions of apoptotic activity through the activity of caspase-7 and caspase- 9 in young children with acute inflammatory diseases of the respiratory organs have not been studied.

\section{Aim}

The objective is to determine the activity of apoptosis processes in young children with anemia of inflammation acquired on the background of acute bacterial diseases of respiratory organs.

\section{Materials and methods}

87 kids at the ages from 2 months to 3 years (the average age of patients was $1.6 \pm 0.3$ years) were under the supervision. Main group included 57 kids with acute bacterial diseases of the respiratory tract, among which 38 patients were diagnosed with acute bacterial bronchitis, and 19 children had pneumonia. The study of the microbial spectrum of biomaterial from the mucous membranes of the oropharynx was performed prior to the appointment of antibacterial therapy on the $2^{\text {nd }}-3^{\text {rd }}$ day of the disease using the bacteriological analyzer VITEK 2 COMPACT (BioMerieux, France) using the AES software: Global CLSI-based + Phenotypic. Causative agents of acute bacterial bronchitis were dominantly $\mathrm{Hae}$ mophillus influenza - 18 (47.4\%) kids and Streptococcus pneumoniae - 12 (31.6\%) kids. Etiology of a pneumonia in supervised children groups most often included Streptococcus pneumoniae - 10 (52.6\%) kids, Klebsiella pneumoniae - $3(15.7 \%)$ patients and Haemophillus influenzae $-3(15.7 \%)$ kids. A titer of a bacterial pathogen 
Table 1. The content of serum markers of apoptosis in examined children

\begin{tabular}{l|l|l|l}
\multirow{2}{*}{ Indicator } & \multicolumn{2}{l|}{ Main group, $\mathbf{n = 5 7}$} & \multirow{2}{*}{ Experimental group, $\mathbf{n = 1 0}$} \\
\cline { 2 - 3 } & Subgroup 1, $\mathbf{n = 2 7}$ & Cubgroup 2, $\mathbf{n = 3 0}$ & $0.38 \pm 0.03$ \\
Caspase-7, $\mathrm{ng} / \mathrm{ml}$ & $0.27 \pm 0.02^{1,3}$ & $0.32 \pm 0.02$ & $10.31 \pm 0.69^{2}$ \\
Caspase-9, $\mathrm{ng} / \mathrm{ml}$ & $13.26 \pm 1.96^{2}$ & $9.88 \pm 0.87^{1}$ & $27.13 \pm 0.81^{1}$ \\
\hline K-9/K-7, relative units & $49.11 \pm 2.50^{2,3}$ & $30.87 \pm 1.03^{1}$ & 0.01 \\
\hline
\end{tabular}

1: $P<0.05$, the significance of differences compared with the control group indicators; $2: P<0.01$, the significance of differences in comparison with the indicators of the control group indicators; $3: P<0.05$, the significance of differences compared with the indicators of the experimental group.

over $10^{5}$ was considered diagnostically significant. Other causative agents were in single-shot suits. Depending on the hematological picture, the main group patients were divided into two subgroups. The first subgroup included 27 children with developed anemia of inflammation acquired on the background of acute bacterial disease of the respiratory tract. Infants were included in the first subgroup of the main group showed deterioration in their general condition 3-4 days after hospitalization, the complete blood test showed the presence of leukocytosis and neutrophilia. Second subgroup included 30 children with acute bacterial diseases of the respiratory tract without anemia. Experimental group included 10 children with iron deficiency anemia who did not have symptoms of inflammatory diseases of the respiratory system. The control group was represented by 20 conditionally healthy children. Observation groups were representative by age and sex of children.

The content of caspase- 7 and caspase- 9 in blood serum was determined by EIA method using commercial kits: RayBio Human CASP7 ELISA Kit (RayBiotech, USA), Human Caspase-9 ELISA Kit (Bender MedSystems $\mathrm{GmbH}$, Austria). Statistical data analysis was performed using the statistical packages "Excel" and "Statistica 13.0" (StatSoftInc., JPZ8041382130ARCN10-J) with the calculation of the standard error of the arithmetic mean (M) and standard deviation $(\sigma)$. To assess differences of the indicators in the compared groups, Student's t-test was used. Differences were considered significant at $P<0.05$.

All procedures performed in studies involving human participants were in accordance with the ethical standards of the institutional and national research committee and with the 1964 Helsinki declaration and its later amendments or comparable ethical standards. Informed consent was obtained from all individual participants included in the study. The full data set by children, their parents, and physician that support the findings of this study are not publicly available due to the restrictions of the ethics approval originally obtained.

\section{Results}

Analysis of the data showed that the development of inflammatory bacterial diseases in children came amid apoptosis increasing that manifested a two-fold increase $(P<0.01)$ of caspase-9 in the blood serum, which serves as an activator of the caspase cascade. The results obtained are logical, taking into account the fact that bacterial endo- and exotoxins act as inducers of programmed cell death.
Taking into consideration the fact that the study group included children with bacterial bronchitis and pneumonia, the levels of caspase- 9 were additionally studied with account of the nosological form of the disease. It was established that the presence of pneumonia in children was accompanied by the highest numbers of caspase- 9 $(14.8 \pm 1.8 \mathrm{ng} / \mathrm{ml})$, which was almost 3 times higher than in the control group. At the same time, the levels of the studied enzyme in patients with bacterial bronchitis were 1.6 times lower $(8.34 \pm 0.90 \mathrm{ng} / \mathrm{ml})$, which, nevertheless, was significantly higher $(P<0.05)$ than in the control group.

Analyzing the content of caspase- 9 against the presence of inflammation anemia in children from the main group (Table 1), it was established that the highest level of caspase- 9 was in the $1^{\text {st }}$ subgroup of children, significantly exceeding the indicators of the control group $(P<0.01)$. At the same time, the content of the key marker of apoptosis (caspase- 9 ) in the $2^{\text {nd }}$ subgroup did not significantly differ from the results obtained in the experimental group, although it was statistically higher than in the control group $(P<0.05)$.

Thus, as a result of performed comparisons, it was established that both in the main group and the comparison group, activation of the first link of the apoptosis process was observed, i.e. there was its initialization.

Having assessed the content of caspase- 7 in the groups of children examined, we noted a different trend. The content of caspase- 7 in blood serum of children of the experimental group and the 2nd subgroup of the main group did not differ from the control group indicators $(P>0.05)$, and children of the 1st subgroup showed its significant decrease. It means, we observed the absence of activation of the caspase "cascade" effector link. For detailing of the above assumption, we calculated the ratio of caspase- 9 to caspase-7 (K-9/K-7), which, in our opinion, will allow us to assess more fully the activity of various links of proteolytic cascade of caspases in examined children. The comparisons confirmed the earlier suggestion. We observed a statistically significant increase in the coefficient calculated in subgroups of children from both the main group and the experimental group. Moreover, we observed the most significant imbalance in the first subgroup, i.e. in children who had anemia of inflammation on the background of acute bacterial diseases of respiratory organs. On the other hand, the absence of significant activation of caspase-7 may indicate different involved effector pathways of inducing apoptosis, particularly, caspase-3.

\section{Discussion}

A detailed study of the apoptosis process modified the concept of cell death. In contrast to necrosis, 
the apoptotic activity is perceived as a natural and necessary process for the normal functioning of organs and systems [7]. A growing number of studies support the fact that the disruption of the apoptosis process leads to the development of inflammatory diseases, including infectious etiology [8]. The number of cells involved in apoptosis is in direct proportion to the balance of proand antiapoptotic factors. The inducers of programmed cell death are viral and bacterial infections, among others. The consequence of the infectious process is associated with the result of opposition to the anti-apoptotic properties of infectious agents and activation of the physiological death of an infected cell as an integral protective mechanism of the body [9]. Therefore, high indicators of caspase- 9 are natural in children of the main group. Taking into account that caspase- 9 is the initiator of the programmed cell death process, in the case of an inflammatory process in cells, its activity will be entirely focused on spreading the signal of cell death and immediate activation of caspase- 3 and, in a less degree, caspase-7 for the physiological death of an infected cell as an integral defense mechanism of the body [10]. This would ensure that cells with active apoptosome, will continue to die even in the absence of effector caspases [11].

At the present stage it is needless to say about the role of iron in the inflammatory process and its active consumption by pathogens. In this regard, depositing it in the cells of the reticuloendothelial system and the development of relative iron deficiency is acting as defense mechanism directed to the localization of the inflammatory process and slowing down the fission pathogen. It is obvious that available iron deficiency can lead to dysfunction of the mitochondrial respiratory chain, which in turn will result in inhibition of cell proliferation or induction of apoptosis [12,13].

According to J. Kovář et al. (1997) iron deprivation can specifically induce apoptosis. Some cell types are sensitive to induction of apoptosis during iron deposition, while other cell types are resistant to it [14]. It was demonstrated, that most cells that are sensitive to the induction of apoptosis during iron deprivation have hematopoietic origin [15].

It is known that, caspase-7 has an effector function in apoptosis. However, apoptosis plays a special role in the final stage of inflammation, when the activated cells of the immune system are eliminated [16]. It is possible to assume that the relatively low (in relation to caspase-9) indicators of the content of caspase-7 in blood serum in children of the main group and, first of all, of the first subgroup are connected precisely because the disease was at the stage of clinical height, when cell death played the leading role due to necrosis, which, possibly, inhibited the apoptosis process [17]. The ineffectiveness of the implementation of apoptosis is due to increased necrotic processes, which arise because of an increase in the severity of the disease [18]. In turn, the delay in the implementation of apoptosis enhances the permeability of inflammatory cells and supports the pathological process. Damage of apoptosis intensity can act as the result of chronic infection or formation of immunodeficient states [19].
Brentnall M. et al (2013) suggest different roles for caspase-9, caspase- 3 and caspase-7 during internal apoptosis. According to researchers, cell death is more effective in the presence of caspase- 3 , which is the main performer of apoptotic death. In contrast, caspase-7 mainly plays a supporting role in the apoptosis implementation phase [11]. These data are the evidence that it is necessary to conduct additional researches to study the functions and roles of each of the caspases during internal apoptosis.

\section{Conclusions}

1. Anemia of inflammation in children with acute bacterial diseases of respiratory organs is accompanied by the activation of apoptosis, which, obviously, is inefficient due to the nature of the active necrotic processes acquired on the background of acute inflammation.

2. With dominant necrotic (inflammatory) process in patient, apoptosis can be inhibited even in case of high activity of the initiating caspase.

Prospects for further research. This work does not reveal the problem of studying the state of apoptosis in the studied group of children in full. The topic requires further study, including the content of caspase-3.

Conflicts of interest: authors have no conflict of interest to declare. Конфмікт інтересів: віАсутній.

Надійшла Ао редакції / Received: 20.03.2019

Після Аоопрацювання / Revised: 03.05.2019

Прийнято Ао Аруку / Accepted: 06.05.2019

Information about authors:

Lezhenko H. O., MD, PhD, DSc, Head of the Department of Hospital Pediatrics, Zaporizhzhia State Medical University, Ukraine.

Abramov A. V., MD, PhD, DSc, Professor of the Department of Pathological Physiology, Head of Scientific MedicalLaboratory Center, Zaporizhzhia State Medical University, Ukraine.

Pohribna A. 0., PhD Student of the Department of Hospital Pediatrics, Zaporizhzhia State Medical University, Ukraine.

\section{Відомості про авторів:}

^еженко Г. О., А-р меА. наук, професор, зав. каф. госпітальної пеліатрії, Запорізький державний меАичний університет, україна.

Абрамов А. В., А-р меА. наук, професор каф. патологічної фізіології, начальник навчального медико-лабораторного центру, Запорізький державний медичний університет, Україна.

Погрібна А. О., PhD аспірант каф. госпітальної педіатрії, Запорізький державний медичний університет, Україна.

\section{Сведения об авторах:}

^еженко Г. А., А-р меА. наук, профессор, зав. каф. госпитальной педиатрии, Запорожский госуАарственный медицинский университет, Украина.

Абрамов А. В., А-р меА. наук, профессор каф. патологической физиологии, начальник учебного меАико-лабораторного центра, Запорожский государственный медицинский университет, Украина.

Погребная А. A., PhD аспирант каф. госпитальной педиатрии, Запорожский государственный медицинский университет, Украина. 


\section{References}

[1] Blokhin, D. Yu. (2003) Programmirovannaya gibel' kletok: put' ot indukcii do ispolneniya [Programmed cell death: from induction to performance]. Patogenez, 2, 25-33. [in Russian].

[2] van Delft, M. F., Smith, D. P., Lahoud, M. H., Huang, D. C. \& Adams, J. M. (2009). Apoptosis and non-inflammatory phagocytosis can be induced by mitochondrial damage without caspases. Cell Death \& Differentiation, 17(5), 821-832. doi: 10.1038/cdd.2009.166

[3] Novikov, V. V., Baryshnikov, A. Yu., \& Karaulov, A. V. (2007). Rastvorimye formy membrannykh antigenov kletok immunnoj sistemy [Soluble forms of membrane antigens of cells of the immune system]. Immunologiya, 4, 249-253. [in Russian].

[4] Laskay, T., van Zandbergen, G., \& Solbach, W. (2008). Neutrophil granulocytes as host cells and transport vehicles for intracellular pathogens: Apoptosis as infection-promoting factor. Immunobiology, 213(3-4), 183-191. doi: 10.1016/j.imbio.2007.11.010

[5] Bulgakova, V. A. (2009) The clinical significance of studying markers of activation and apoptosis of immunocompetent cells in children with atopic bronchial asthma. Pediatriya, 87(2), 12-18.

[6] Pavlyshyn, H. A., Sarapuk, I. M., \& Sarapuk, H. S. (2013). Osoblyvosti apoptozu pry riznykh patolohichnykh protsesakh [Peculiarities of apoptosis in various pathological processes]. Neonatolohiia, khirurhiia ta perynatalna medytsyna, 4, 118-122.

[7] Vyaltseva, Yu. V. (2007). Rol apoptozu pry infektsiinykh khvorobakh [Role of apoptosis at infectious diseases]. Infektsiini khvoroby, 1, 57-63. [in Ukrainian]

[8] Kondrashova, N. M., Plekhova, N. G., Zavorueva, D. V., Somova, L. M., Geltser, B. I., \& Kostyushko, A. V. (2010) Kletochnye faktory mestnoj zashhity pri vnebol'nichnoj pnevmonii [Cellular factors of local protection under community acquired pneumonia]. Cytology, 57(7), 588. [in Russian].

[9] Mcllwain, D., Berger, T., \& Mak, T. (2013). Caspase Functions in Cell Death and Disease. Cold Spring Harbor Perspectives in Biology, 5(4), a008656. doi: 10.1101/cshperspect.a008656

[10] Guicciardi, M., \& Gores, G. (2009). Life and death by death receptors. The FASEB Journal, 23(6), 1625-1637. doi: 10.1096/fj.08-111005

[11] Brentnall, M., Rodriguez-Menocal, L., De Guevara, R., Cepero, E., \& Boise, L. (2013). Caspase- 9 , caspase- 3 and caspase- 7 have distinct roles during intrinsic apoptosis. BMC Cell Biology, 14(1), 32. doi: 10.1186/1471-2121-14-32

[12] Rakba, N., Loyer, P., Gilot, D., Delcros, J. G., Glaise, D., Baret, P., et al. (2000). Antiproliferative and apoptotic effects of O-Trensox, a new synthetic iron chelator, on differentiated human hepatoma cell lines. Carcinogenesis, 21(5), 943-951. doi: 10.1093/carcin/21.5.943

[13] Simonart, T., Heenen, M., Degraef, C., Andrei, G., Mosselmans, R., Hermans, P., et al. (2000). Iron Chelators Inhibit the Growth and Induce the Apoptosis of Kaposi's Sarcoma Cells and of their Putative Endothelial Precursors. Journal of Investigative Dermatology, 115(5), 893-900. doi: 10.1046/j.1523-1747.2000.00119.x

[14] Kováŕ, J., Kühn, L., Richardson, V., Seiser, C., Kriegerbecková, K., \& Musilková, J. (1997). The inability of cells to grow in low iron correlates with increasing activity of their iron regulatory protein (IRP). In Vitro Cellular \& Developmental Biology Animal, 33(8), 633-639. doi: 10.1007/ s11626-997-0114-2

[15] Koc, M., Nad'ová, Z., \& Kováŕ, J. (2006). Sensitivity of cells to apoptosis induced by iron deprivation can be reversibly changed by iron availability. Cell Proliferation, 39(6), 551-561. doi: 10.1111/j.13652184.2006.00411.x

[16] Ryazantseva, N. V., Zhavoronok, T. V., Stepovaya, E. A., Starikov, Y. V., Ageeva, T. S., Mitasov, V. Y., \& Sokolovich, E. G. (2010) Okislitel'nyj stress v modulyacii apoptoza nejtrofilov v patogeneze ostrykh vospalitel'nykh zabolevanij [Oxidative stress in neutrophil cell death modulation during pathogenesis of acute inflammatory diseases]. Byulleten' Sibirskogo otdeleniya Rossijskoj akademii medicinskikh nauk, 30(5), 58-63. [in Russian].

[17] Oved, K, Cohen, A, Boico, O., Navon, R., Friedman, T., Etshtein, L., et al. (2015) A Novel Host-Proteome Signature for istinguishing between Acute Bacterial and Viral Infections. PLoS One, 10(3), e0120012. doi: 10.1371/journal.pone.0120012

[18] Pavlyshyn, H. A., \& Sarapuk, I. M. (2013) Pokaznyky efektyvnosti obektyvizatsii otsinky klinichnoho perebihu nehospitalnoi pnevmonii u ditei rannoho viku [Parameters of effectiveness of objectification of evaluation of clinical course of hospitalized pneumonia in children of early age]. Visnyk naukovykh doslidzhen, 2, 62-66. [in Ukrainian].

[19] Hallett, J. M., Leitch, A. E., Riley, N. A., Duffin, R., Haslett, C., \& Rossi, A. G. (2008). Novel pharmacological strategies for driving inflammatory cell apoptosis and enhancing the resolution of inflammation. Trends in Pharmacological Sciences, 29(5), 250-257. doi: 10.1016/j. tips.2008.03.002 